\title{
17. ASH LAYERS FROM DEEP SEA DRILLING PROJECT LEG 84: MIDDLE AMERICA TRENCH TRANSECT ${ }^{1}$
}

\author{
A. Pouclet and J. P. Cadet, Département des Sciences de la Terre, Université d'Orléans \\ K. Fujioka, Ocean Research Institute, University of Tokyo \\ and \\ J. Bourgois, Département de Géotectonique, Université Pierre et Marie Curie ${ }^{2}$
}

\begin{abstract}
Three Leg 84 sites provided a good record of explosive volcanism onshore (in Central America). Ash layers and many ashy pods are interbedded in Recent to Oligocene strata. Evidence of the main periods of activity was noted in Recent to upper Pleistocene, Pliocene-Pleistocene, lower Pliocene to upper Miocene, lower Miocene, and upper Oligocene. Noticeable traces of older volcanism were found in upper Eocene strata.

The chemical analyses of glass shards show a dacitic to rhyolitic composition with a low to moderate calc-alkalinity. A preliminary distinction of samples in three geochemical groups according to their $\mathrm{K}_{2} \mathrm{O} / \mathrm{SiO}_{2}$ contents is done to test a magmatic evolution. Comparisons are made with Leg 67 and on-land data.
\end{abstract}

\section{INTRODUCTION}

During Leg 84 the landward slope of the Middle America Trench off Guatemala was drilled (Fig. 1). At the sites where basement was penetrated, it was found to consist of ophiolitic rock (Aubouin, von Huene, et al., 1982) covered by sediments of the early Eocene (Sites $569,570)$, the late Oligocene-early Miocene overlying Late Cretaceous (567), and the late Miocene $(566,568)$. The sites are distributed along a traverse roughly perpendicular to the margin (Fig. 2) and provide the opportunity to establish a chronology of airborne volcanic ashes interbedded within the sediments. The data of both Leg 66 north of Tehuantepec Ridge and of Leg 67 off Guatemala gave good records of explosive volcanism onshore because of the location of the sites close to volcanic sources and because of the direction of prevailing winds and marine currents.

\section{ASH AT LEG 84 SITES}

Drilling was done at five sites, but Site 567, at the base of the slope, and Site 566, $22 \mathrm{~km}$ upslope from the axis of the Trench (Fig. 2), were devoid of significant ash layers. At three sites good stratigraphic samples were recovered.

\section{Site 569}

Site 569 is located at a depth of $2770 \mathrm{~m} \mathrm{(27} \mathrm{km} \mathrm{from}$ the Trench axis and $125 \mathrm{~km}$ south of the coast of Guatemala). Ash layers are present in Pleistocene to upper Oligocene strata (Fig. 3). They are more numerous in the Pleistocene, where 17 thin ( $2 \mathrm{~cm}$ average) and fine-grained

\footnotetext{
1 von Huene, R., Aubouin, J., et al., Init. Repts. DSDP, 84: Washington (U.S. Govt. Printing Office).

2 Addresses: (Pouclet and Cadet) Département des Sciences de la Terre, Université d'Orléans, 45046 Orléans, France; (Fujioka) Ocean Research Institute, University of Tokyo, Minamidai, Nakano-Ku, 164 Tokyo, Japan; (Bourgois) Département de Géotectonique, Université Pierre et Marie Curie, 75230 Paris, France.
}

(fine silt generally) ash layers and many ash pods are interbedded in mud, and in the lower Miocene, where 29 ash beds can be counted. Colors range from very light gray to white (N8, N9) (in this case beds are rich in volcanic glass, $60-80 \%$ ), to light gray olive (10Y $4 / 2)$, and olive-black (5Y 2/1) with marked amounts of quartz, alkaline feldspar, plagioclase, pyroxene, and amphibole. Upper Oligocene ashes are pale reddish purple (5NP 6/ 2 ) in Core 569A-2 and medium gray (N4) in Core 569A7; these ashes are more clay-rich (Fig. 4). The oldest hemipelagic sediments of the Eocene (Core 569A-9) contain some traces of volcanic activities - fragments of glass, quartz, and feldspar disseminated in bioturbated mudstone; but no ash layers were recorded because of poor core recovery.

\section{Site 568}

Site 568 is located at a depth of $2031 \mathrm{~m}$ on the upper slope, about $45 \mathrm{~km}$ from the Trench axis. Recent to upper Pleistocene muds contain 17 distinct thin layers of ash, as at Site 569, and numerous ashy mottles and pumice clasts; these occur mainly in the upper part of the section. Colors vary from light gray (N7) to medium bluish gray (5B 5/1) and olive black (5Y 2/1) to pale olive (10Y 4/2). Grain size ranges from very fine silt (most commonly) to silt.

Upper Miocene to lower Miocene-upper Oligocene mudstones, above Core 568-41, contain numerous (30) ash layers as well as numerous ashy mottles and pumice clasts, mainly in middle Miocene strata. Some beds are rich (5-7\%) in biotite, for example, Samples 568-7-1, $139-141 \mathrm{~cm}$ or $568-29-1,59-61 \mathrm{~cm}$. Glass percentage decreases downsection (25-35\% in Oligocene) because of alteration.

\section{Site 570}

Site 570 is located on the edge of a small bench in the upper slope, $40 \mathrm{~km}$ north of the Trench axis. Ash layers 


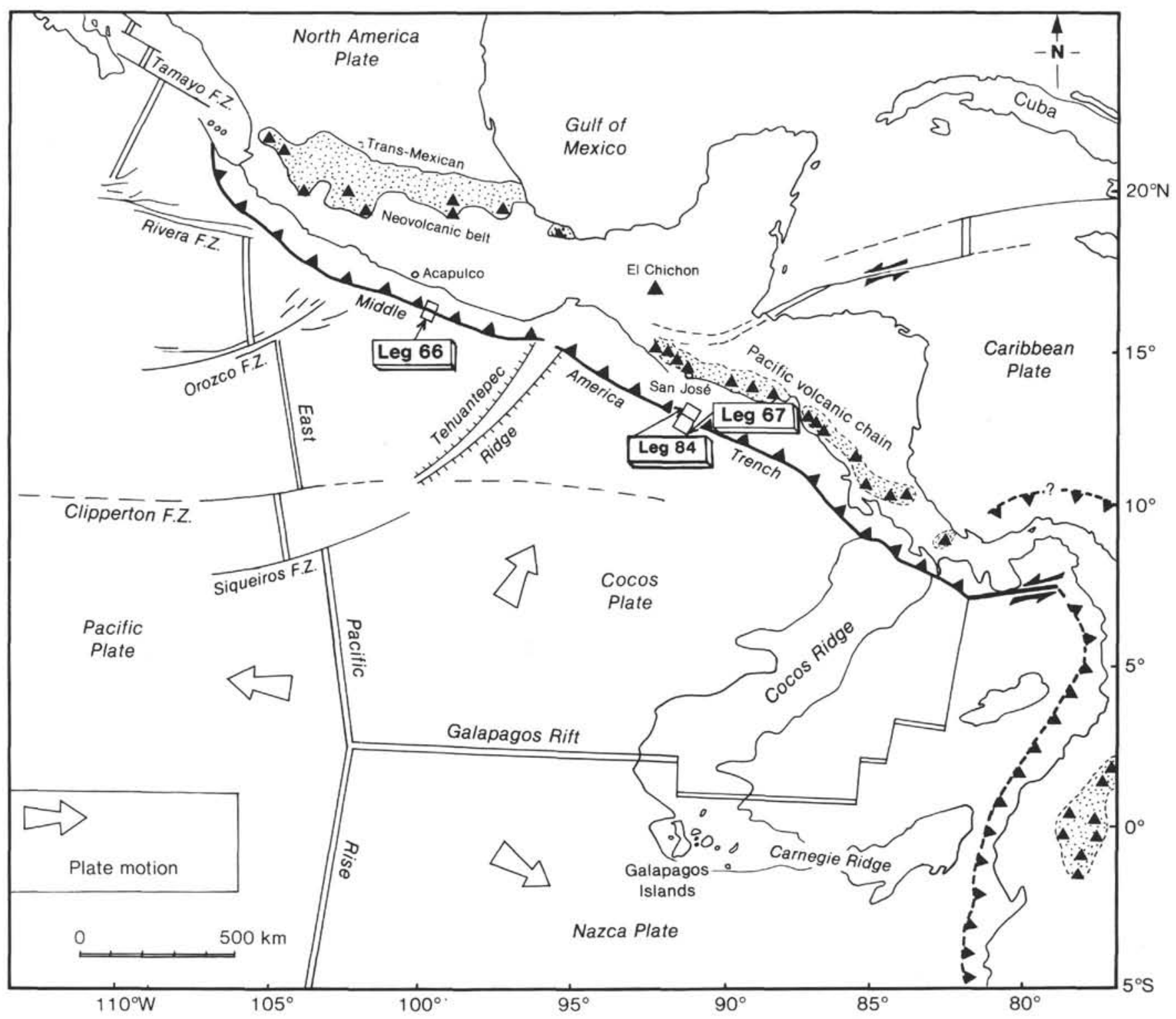

Figure 1. Geological setting of Legs 84, 66, and 67. Eastern Cocos Plate boundary after Lonsdale and Klitgord (1978).

occur mainly in Pleistocene mud (10 counted). They vary in color from very light gray (N8) (the richest in volcanic glass, up to $90 \%)$ to moderate olive brown $(5 \mathrm{Y} 4 / 4)$ and olive gray (5Y $3 / 2)$. Thickness of ash layers is slightly greater, reflecting the site's proximity to land, and graded beds containing quartz and feldspars in amounts up to $20 \%$ occur. In upper Miocene sediment, ash beds are scarce ( 3 counted); they are medium light gray (N6) and fine-grained.

\section{GEOCHEMISTRY}

\section{METHOD}

Nineteen ash layers were sampled at Sites 569,568 , and 570 from the Trench upper slope to the foot of the continental talus. Their age ranges from late Oligocene to Recent. Figure 5 gives the distribution of analyzed samples. Fifty-six specimens of glass shards were analyzed using a JEOL EPMA (JCXA 733) electron-probe microanalyzer at the Ocean Research Institute, Tokyo University. The analyses were per- formed using a $15-\mathrm{kV}$ accelerating voltage, and $20-\mu \mathrm{m}$ average defocused beam diameter, 10-s count time, with the elements ordered as follows: $\mathrm{Na}, \mathrm{K}, \mathrm{Si}, \mathrm{Fe}, \mathrm{Mg}, \mathrm{Al}, \mathrm{Ti}, \mathrm{Mn}, \mathrm{Ca}, \mathrm{Ni}$, and $\mathrm{Cr}$.

\section{Chemical Composition of Glass Shards}

$\mathrm{SiO}_{2}$ contents range from 58.14 to $73.30 \%$ (Table 1); most samples have acidic compositions. The analyses total between 91 to $95 \%$. This important deficit is a wellknown problem in ash analysis. As the selected samples are devoid of apparent alteration, this deficit could be accounted for by hydration of glass and analytical error. Because the iron content is very low, oxidation of iron cannot be responsible for the low totals. It is difficult to analyze glasses with a microprobe owing to the volatility of elements such as $\mathrm{Na}$ and $\mathrm{K}$ in this kind of material. However, a significant drift only appears after a count time exceeding $30 \mathrm{~s}$. In order to avoid this problem, the most volatile elements were analyzed first with short 


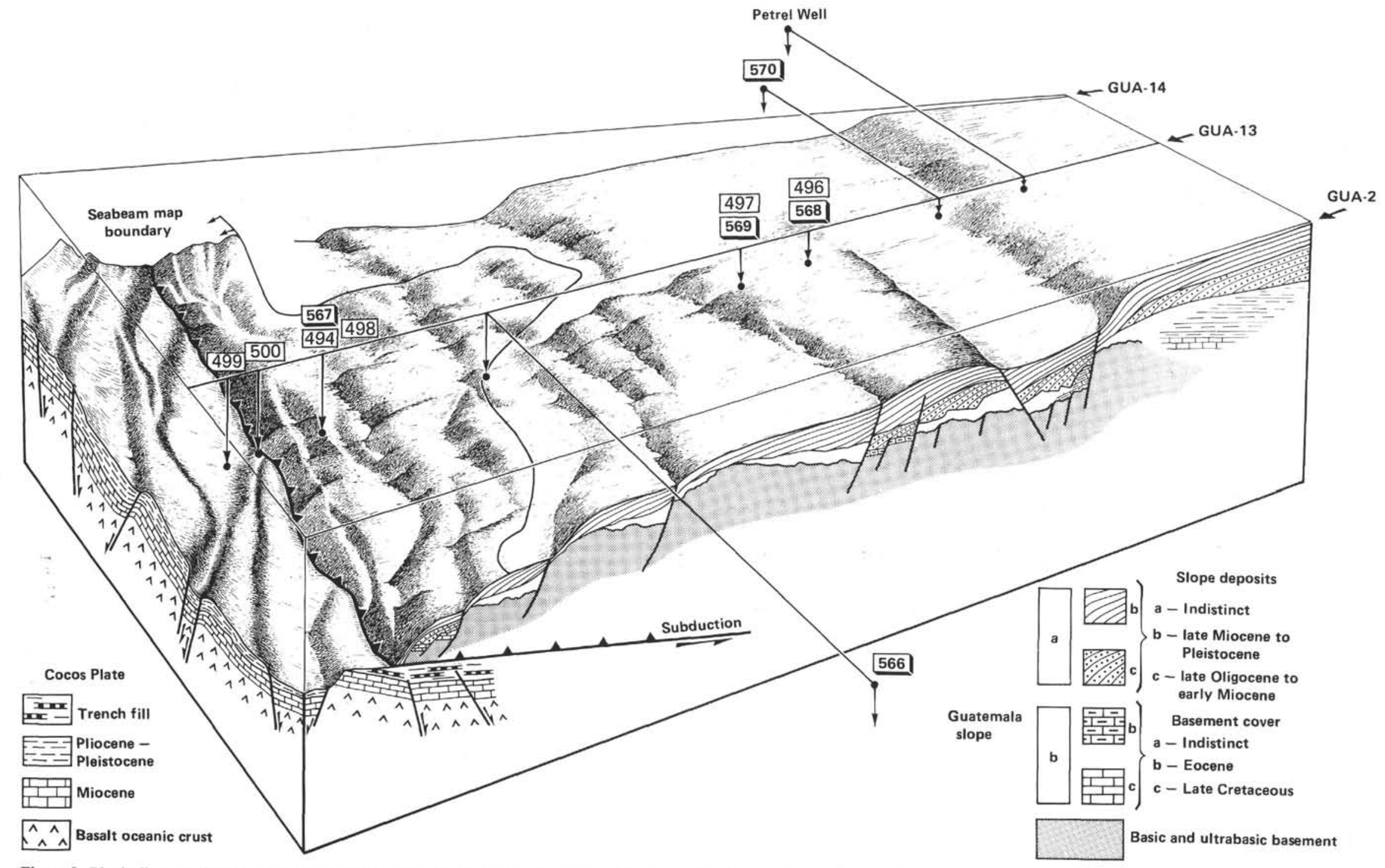

Figure 2. Block diagram showing the position of Guatemalan Leg 84 and some Leg 67 sites on the landward wall of the Middle America Trench (after Aubouin, von Huene, et al., 1982). 


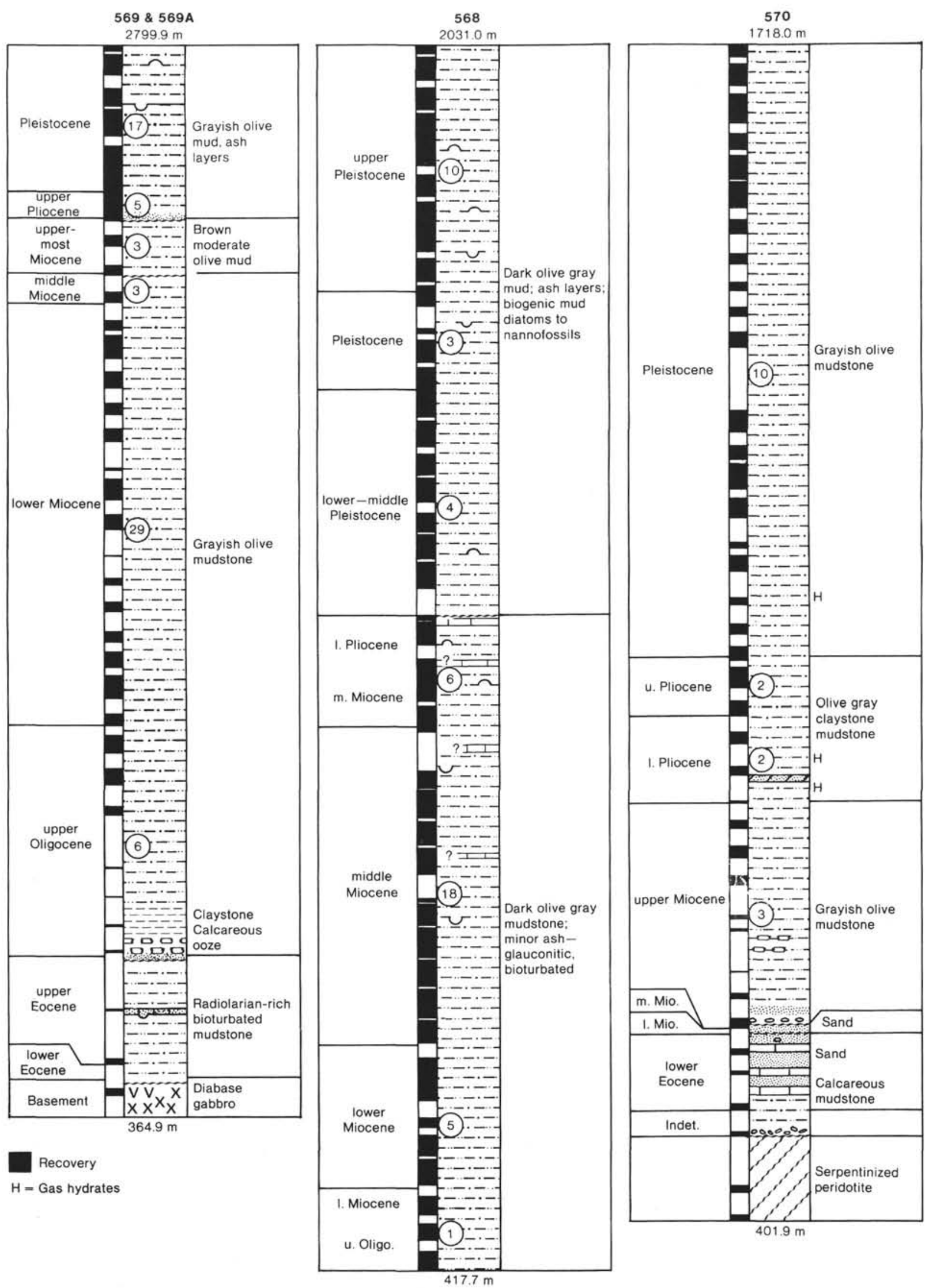

Figure 3. Holes 569, 569A, 568, and 570 simplified stratigraphic columns; circled numbers show the number and position of ash layers in the recovered sediment sections. 


\begin{tabular}{|c|c|c|c|c|c|c|c|c|}
\hline \multirow[t]{2}{*}{ Age } & \multirow{2}{*}{\begin{tabular}{|c|}
$\begin{array}{c}\text { Sample } \\
\text { (core-section, } \\
\text { interval in cm) }\end{array}$ \\
$\begin{array}{c}\text { Holes } 569 \\
\text { and } 569 \mathrm{~A}\end{array}$ \\
\end{tabular}} & \multirow{2}{*}{\begin{tabular}{|l|}
$\begin{array}{l}\text { Volcanic } \\
\text { glass } \\
(\%)\end{array}$ \\
0
\end{tabular}} & \multirow{2}{*}{ 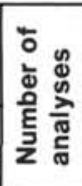 } & \multirow[t]{2}{*}{$\begin{array}{c}\text { Clay } \\
(\%)\end{array}$} & \multirow[t]{2}{*}{$\begin{array}{c}\text { Quartz } \\
(\%)\end{array}$} & \multirow[t]{2}{*}{$\begin{array}{c}\text { Feldspar } \\
(\%)\end{array}$} & \multirow[t]{2}{*}{$\begin{array}{c}\text { Heavy } \\
\text { minerals } \\
(\%)\end{array}$} & \multirow[t]{2}{*}{$\begin{array}{c}\text { Fossils } \\
(\%)\end{array}$} \\
\hline & & & & & & & & \\
\hline $\begin{array}{l}\text { lower Pleist.- } \\
\text { upper Pliocene }\end{array}$ & $\begin{array}{c}7-2 \\
139-141\end{array}$ & 8 & 3 & EDx & 8 & t & 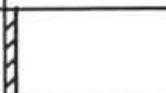 & 1 \\
\hline middle Miocene 5 & $\begin{array}{c}10, \mathrm{CC} \\
(16-18)\end{array}$ & EDA & 7 & 8 & $\theta$ & . & 1 & 1 \\
\hline lower Miocene 6 & $\begin{array}{c}11-1 \\
78-80\end{array}$ & 81 & 4 & Ex & 8 & te & t & 8 \\
\hline \multirow[t]{2}{*}{$\begin{array}{l}\text { upper } \\
\text { Oligocene }\end{array}$} & $\begin{array}{c}\text { A7-1, } \\
83-85 \\
\end{array}$ & EDA & 2 & 8 & 8 & 1 & 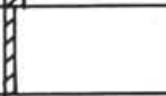 & 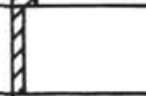 \\
\hline & Hole 568 & & & & & & & \\
\hline \multirow{2}{*}{ Recent } & $\begin{array}{c}5-5, \\
38-40\end{array}$ & EDID & 2 & 8 & 1) & 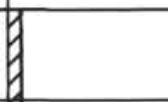 & 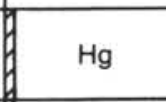 & , \\
\hline & $\begin{array}{c}5-7 \\
20-22\end{array}$ & EDID & 2 & 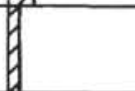 & 10 & , & $\mathrm{Hb}$ & 1 \\
\hline $\begin{array}{l}\text { upper } \\
\text { Pleistocene }\end{array}$ & $\begin{array}{c}10-1 \\
97-99\end{array}$ & EDA & 5 & . & 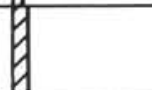 & 1) & $\mathrm{Hg}$ & 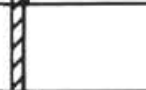 \\
\hline $\begin{array}{l}\text { lower Pleist.- } \\
\text { upper Pliocene }\end{array}$ & $\begin{array}{l}20-7 \\
7-9\end{array}$ & EDy & 3 & 4 & 1 & , & $\mathrm{Hg}$ & 8 \\
\hline $\begin{array}{l}\text { lower } \\
\text { Pliocene }\end{array}$ & $\begin{array}{c}23-2 \\
90-92\end{array}$ & EDA & 3 & 8 & 8 & t & t & . \\
\hline \multirow{5}{*}{$\begin{array}{l}\text { middle } \\
\text { Miocene }\end{array}$} & $\begin{array}{c}27-4 \\
88-90\end{array}$ & DDA & 1 & $y$ & 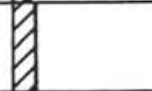 & ty & 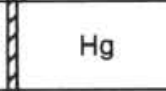 & 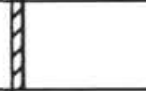 \\
\hline & $\begin{array}{c}29-1 \\
59-61\end{array}$ & EDA & 1 & 8 & $\theta$ & t) & 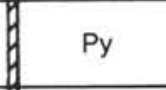 & \\
\hline & $\begin{array}{c}29-1 \\
138-139\end{array}$ & EDA & 4 & 4 & 8 & 8 & 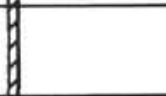 & 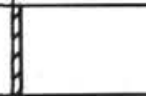 \\
\hline & $\begin{array}{c}35-6 \\
76-78\end{array}$ & EDy & 7 & 8 & $\theta$ & (1) & 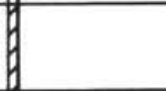 & 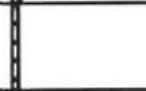 \\
\hline & $\begin{array}{c}37-4 \\
39-41\end{array}$ & 1111 & 1 & 4 & 1 & t) & 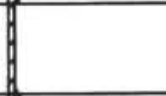 & \\
\hline \multirow[t]{2}{*}{$\begin{array}{l}\text { lower } \\
\text { Miocene }\end{array}$} & $\begin{array}{c}38-1 \\
120-122 \\
\end{array}$ & DIIA & 4 & 1 & 1 & 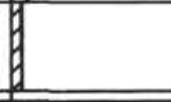 & . & \\
\hline & Hole 570 & & & & & & & \\
\hline \multirow{2}{*}{ Present } & $\begin{array}{c}2-1 \\
141-143\end{array}$ & DDDP & 3 & t & 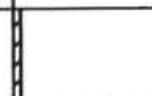 & 1 & , & \\
\hline & $\begin{array}{c}2-3 \\
108-110\end{array}$ & DIIX & 2 & 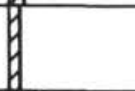 & 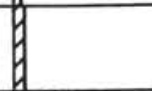 & 8 & 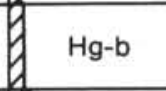 & \\
\hline $\begin{array}{l}\text { lower Pleist.- } \\
\text { upper Pliocene }\end{array}$ & $\begin{array}{c}23-2 \\
74-76 \\
\end{array}$ & Ex & 1 & 8 & 8 & 1 & 8 & 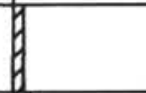 \\
\hline $\begin{array}{l}\text { upper } \\
\text { Miocene }\end{array}$ & $\begin{array}{c}32-4 \\
120-122 \\
\end{array}$ & Ex & 1 & 1 & 1 & 8 & d & 1 \\
\hline
\end{tabular}

Figure 4. Result of smear slide analysis of the electron-probe micro-analyzed samples; distribution and number of analyses of volcanic glass shards. $(\mathrm{H}=$ hornblende, $\mathrm{g}=$ green, $\mathrm{b}=$ brown, $\mathrm{Py}=$ pyrite). 
Table 1. Selected microprobe analyses of glass shards (\%).

\begin{tabular}{|c|c|c|c|c|c|c|c|c|c|c|c|c|c|c|c|c|c|c|}
\hline \multirow{3}{*}{$\begin{array}{c}\text { Sample } \\
\text { (interval in } \mathrm{cm} \text { ) } \\
\text { Petrographic type } \\
\text { Magmatic group } \\
\text { Analysis number }\end{array}$} & \multicolumn{2}{|c|}{$\begin{array}{c}568-5-5,38-40 \\
\text { [1] }\end{array}$} & \multicolumn{2}{|c|}{$\begin{array}{c}568-5-7,20-22 \\
{[1]}\end{array}$} & \multicolumn{2}{|c|}{$\begin{array}{c}568-10-1,97-99 \\
{[2]}\end{array}$} & \multicolumn{2}{|c|}{${ }_{[3]}^{568-20-7,7-9}$} & \multicolumn{3}{|c|}{$\begin{array}{c}568-22-3,90-92 \\
{[4]}\end{array}$} & \multirow{3}{*}{$\frac{568-27-4,88-90}{[5]}$} & \multirow{3}{*}{$\begin{array}{c}568-29-1,59-61 \\
{[5]} \\
D c \\
B \\
29\end{array}$} & \multicolumn{3}{|c|}{$\begin{array}{c}568-29-1,138-139 \\
{[5]}\end{array}$} & \multicolumn{2}{|c|}{$\begin{array}{c}568-35-6,76-78 \\
{[5]}\end{array}$} \\
\hline & $\begin{array}{c}\mathrm{D} c \\
\mathrm{C}\end{array}$ & $\begin{array}{l}\mathrm{Dc} \\
\mathrm{C}\end{array}$ & $\begin{array}{c}\mathrm{Rh} \\
\mathrm{B}\end{array}$ & $\begin{array}{c}\mathrm{Rh} \\
\mathrm{B}\end{array}$ & $\begin{array}{c}\mathrm{Rd} \\
\mathrm{A}\end{array}$ & $\begin{array}{c}\mathrm{Rh} \\
\mathrm{A}\end{array}$ & $\begin{array}{c}\mathrm{Rd} \\
\mathrm{B}\end{array}$ & $\begin{array}{l}\mathrm{Dc} \\
\mathrm{AB}\end{array}$ & $\begin{array}{l}\mathrm{Dc} \\
\mathrm{C}\end{array}$ & $\begin{array}{l}\mathrm{Dc} \\
\mathrm{C}\end{array}$ & $\begin{array}{l}\text { An } \\
\text { C }\end{array}$ & & & $\begin{array}{c}\mathrm{Dc} \\
\mathrm{B}\end{array}$ & $\begin{array}{l}\mathrm{Rd} \\
\mathrm{C}\end{array}$ & $\begin{array}{l}\mathrm{Dc} \\
\mathrm{C}\end{array}$ & $\begin{array}{c}\mathrm{Rd} \\
\mathrm{C}\end{array}$ & $\begin{array}{l}\mathrm{Rd} \\
\mathrm{C}\end{array}$ \\
\hline & 131 & 135 & 14 & 15 & 146 & 149 & 142 & 143 & 136 & 138 & 140 & & & 24 & 25 & 26 & 92 & 93 \\
\hline $\mathrm{SiO}_{2}$ & 66.48 & 67.45 & 73.30 & 73.25 & 70.76 & 72.05 & 71.16 & 68.49 & 69.92 & 65.70 & 58.14 & 72.59 & 68.89 & 68.85 & 70.26 & 69.98 & 71.96 & 70.77 \\
\hline $\mathrm{TiO}_{2}$ & 0.14 & 0.10 & 0.07 & 0.10 & 0.18 & 0.21 & 0.20 & 0.18 & 0.13 & 0.40 & 0.99 & 0.17 & 0.17 & 0.21 & 0.13 & 0.14 & 0.02 & 0.03 \\
\hline $\mathrm{Al}_{2} \mathrm{O}_{3}$ & 14.04 & 13.86 & 12.11 & 12.19 & 12.52 & 12.66 & 12.11 & 14.92 & 13.47 & 14.11 & 15.59 & 11.79 & 13.35 & 13.98 & 12.82 & 12.65 & 12.68 & 12.58 \\
\hline$\Sigma \mathrm{FeO}^{\circ}$ & 1.57 & 1.51 & 0.53 & 0.55 & 1.09 & 1.11 & 1.14 & 0.81 & 0.91 & 2.51 & 6.53 & 0.83 & 0.88 & 0.98 & 0.69 & 0.66 & 0.84 & 0.93 \\
\hline $\mathrm{MnO}$ & 0.06 & 0.06 & 0.08 & 0.05 & 0.15 & 0.07 & 0.02 & 0.05 & 0.08 & 0.12 & 0.16 & 0.06 & 0.07 & 0.07 & 0.09 & 0.08 & 0.02 & 0.10 \\
\hline $\mathrm{MgO}$ & 0.22 & 0.19 & 0.08 & 0.07 & 0.23 & 0.25 & 0.18 & 0.14 & 0.14 & 0.47 & 1.91 & 0.13 & 0.22 & 0.24 & 0.12 & 0.11 & 0.04 & 0.03 \\
\hline $\mathrm{CaO}$ & 1.09 & 1.00 & 0.59 & 0.61 & 1.34 & 1.30 & 0.90 & 2.31 & 0.49 & 1.35 & 4.13 & 0.61 & 0.89 & 0.69 & 0.42 & 0.38 & 0.56 & 0.56 \\
\hline $\mathrm{Na}_{2} \mathrm{O}$ & 3.87 & 3.52 & 3.88 & 3.84 & 3.54 & 3.79 & 3.47 & 4.39 & 4.22 & 3.88 & 4.24 & 3.12 & 3.44 & 4.68 & 4.10 & 3.97 & 3.61 & 2.99 \\
\hline $\mathrm{K}_{2} \mathrm{O}$ & 3.38 & 3.27 & 3.36 & 3.46 & 1.93 & 1.95 & 2.86 & 2.15 & 3.27 & 3.58 & 2.54 & 3.79 & 3.05 & 2.67 & 3.64 & 3.29 & 3.66 & 4.24 \\
\hline $\mathrm{NiO}$ & 0.02 & 0.04 & - & - & - & - & 0.02 & tr & - & - & - & - & 0.01 & - & - & 0.02 & 0.01 & - \\
\hline $\mathrm{Cr}_{2} \mathrm{O}_{3}$ & - & - & - & 0.02 & - & - & 0.01 & 0.01 & 0.01 & 0.03 & - & 0.01 & 0.01 & 0.04 & 0.01 & - & - & - \\
\hline Total & 90.87 & 91.00 & 94.00 & 94.14 & 91.74 & 93.39 & 92.07 & 93.45 & 92.64 & 92.15 & 94.23 & 93.10 & 90.98 & 92.41 & 92.28 & 91.28 & 93.13 & 92.23 \\
\hline
\end{tabular}

Note: Chronostratigraphic group is indicated in brackets below sample number: $1=$ Recent, 2 = upper Pleistocene, $3=$ lower Pleistocene-upper Pliocene, $4=$ lower Pliocene, $5=$ middle Miocene, $6=$ lower Miocene, and $7=$ upper Oligocene. Magmatic groups are $\mathrm{A}=$ low $\mathrm{K}, \mathrm{B}=$ medium $\mathrm{K}, \mathrm{C}=$ high $\mathrm{K}$; petrographic types are $\mathrm{Bs}=$ basalt, An $=$ andesite, $\mathrm{Dc}=$ dacite, $\mathrm{Rd}=\mathrm{rhyodacite}$, and $\mathrm{Rh}$ $=$ rhyolite. Total $\mathrm{Fe}$ as $\mathrm{FeO} ;-=$ not determined; $\mathrm{tr}=$ trace.

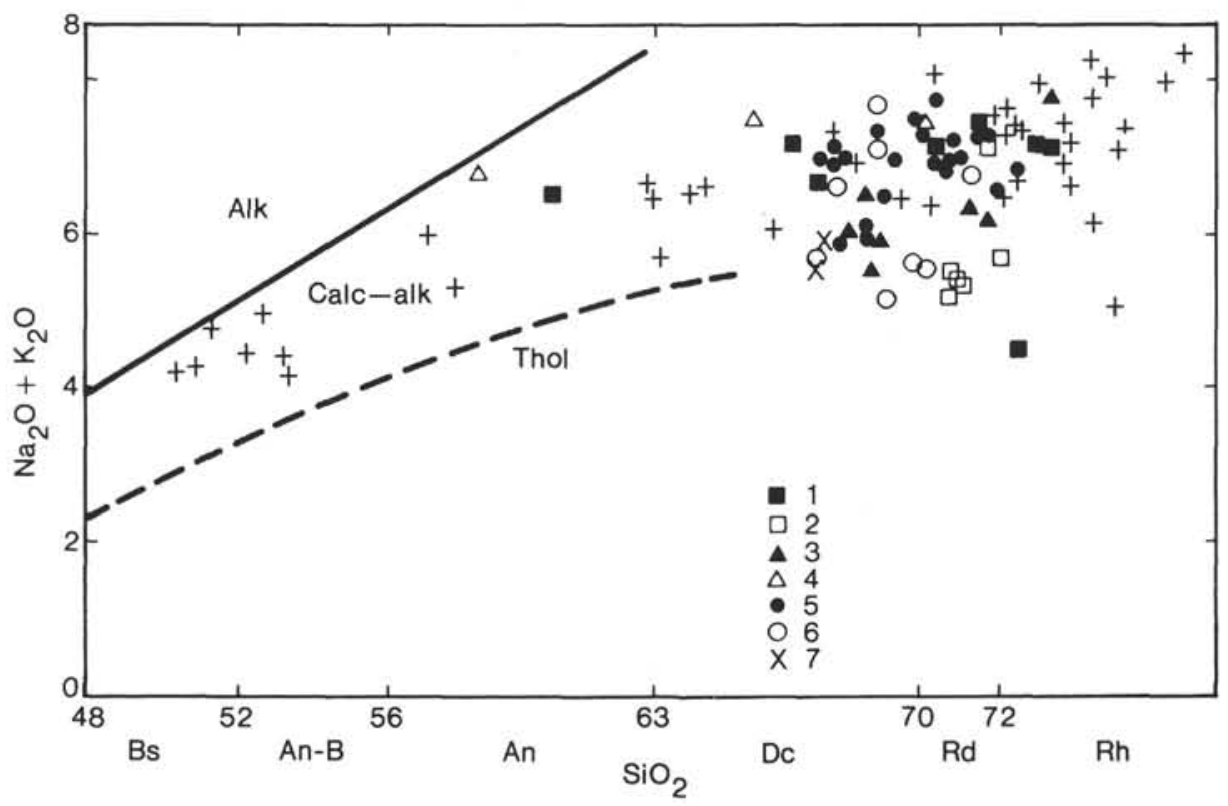

Figure 5. $\left(\mathrm{Na}_{2} \mathrm{O}+\mathrm{K}_{2} \mathrm{O}\right) / \mathrm{SiO}_{2}$ diagram (chronostratigraphic groups: $1=$ Recent; 2 = upper Pleistocene; 3 = lower Pleistocene-upper Pliocene; 4 = lower Pliocene; 5 = middle Miocene; 6 = lower Miocene; 7 = upper Oligocene; $+=$ on-land tephras analyses for comparison (see references in the text). Alk/calc = alkaline/subalkaline lavas boundary (Irvine and Baragar, 1971). Calc-alk/ thol = calc-alkaline/tholeitic lavas boundary (Kuno, 1968). Petrographic identifications are Bs = basalt $; \mathrm{An}-\mathrm{B}=$ basalt andesite $; \mathrm{An}=$ andesite $; \mathrm{Dc}=$ dacite $\mathrm{Rd}=$ rhyodacite $\mathrm{Rh}=$ rhyolite . $\mathrm{SiO}_{2}$ typological boundaries are defined by Pecerillo and Taylor (1976) and are slightly modified for Rd, as in Cadet et al., 1982.

count times and a defocused beam. In agreement with several authors (cf., Cadet et al., 1981 and 1982), we suggest that hydration explains the greatest part of the analytical deficit. Because the deficit is independent of sample age, the hydration must have occurred at the time of deposition. Analysis of row data and data corrected by recalculating to $100 \%$, like a water-free analysis, have been plotted on the same $\mathrm{SiO}_{2}$ /alkaline diagram (not shown). It appears that the corresponding points in the two groups are linked by parallel segments with very few exceptions. Even the proportion of the analyzed elements like the alkaline elements which are the most sensitive to alteration, is not perceptibly modified by the hydration (analytical deficit). In the following discussion, we use the row data from the 56 analyses.

\section{Magmatic Characterization}

Analyses are distributed in chronostratigraphic groups corresponding to the following main periods of volcanic activity: $1=$ Recent, $2=$ upper Pleistocene, $3=$ lower Pleistocene-upper Pliocene, $4=$ lower Pliocene, $5=$ middle Miocene, $6=$ lower Miocene, and $7=$ upper Oligocene.

On the $\mathrm{SiO}_{2}$-total alkaline diagram (Fig. 5), points appear scattered within the calc-alkalkine field, near the boundary of the tholeiitic field. According to the nomen- 
Table 1. (Continued.)

\begin{tabular}{|c|c|c|c|c|c|c|c|c|c|c|c|c|c|c|}
\hline $\begin{array}{c}568-37-4,37-41 \\
{[5]}\end{array}$ & $\begin{array}{r}568-38-1 \\
\end{array}$ & $120-122$ & $\begin{array}{c}569-7-2,139-141 \\
{[3]}\end{array}$ & $569-10, \mathrm{C}$ & (16-18) & 569-11- & $i^{78-80}$ & 569.7. & $83-85$ & $\begin{array}{c}570-2-1,141-143 \\
\text { [1] }\end{array}$ & $570-2-3$ & $108-110$ & $\begin{array}{c}570-23-2,74 \\
{[3]}\end{array}$ & $\begin{array}{c}570-34-2,120-122 \\
{[5]}\end{array}$ \\
\hline $\mathrm{Rh}$ & $\mathrm{Dc}$ & Rd & $\mathrm{Dc}$ & $\mathrm{Dc}$ & Dc & $R d$ & $\mathrm{De}$ & $\mathrm{Dc}$ & $\overline{\mathrm{Dc}}$ & $\mathrm{Rd}$ & $\mathrm{Rd}$ & An & $\mathbf{R h}$ & $\mathrm{Dc}$ \\
\hline C & $\mathrm{A}$ & A & A & C & A & B & C & $\mathrm{A}$ & A & B & B & B & C & C \\
\hline 98 & 34 & 102 & 46 & 54 & 83 & 59 & 77 & 70 & 72 & 13 & 10 & 121 & 8 & 111 \\
\hline 72.02 & 67.22 & 70.13 & 68.61 & 67.52 & 68.56 & 71.24 & 69.82 & 67.24 & 67.42 & 71.55 & 70.21 & 60.26 & 73.26 & 67.59 \\
\hline 0.24 & 0.42 & 0.30 & 0.29 & 0.37 & 0.24 & 0.09 & 0.08 & 0.33 & 0.33 & 0.11 & 0.10 & 0.58 & 0.08 & 0.17 \\
\hline 11.65 & 13.94 & 13.06 & 13.87 & 13.22 & 13.80 & 11.97 & $\begin{array}{l}0.00 \\
13.35\end{array}$ & 14.31 & 13.73 & 12.36 & 12.11 & 15.15 & 12.33 & 13.80 \\
\hline 1.05 & 1.98 & 1.45 & 2.15 & 1.57 & 2.12 & 0.91 & 1.07 & 1.79 & 1.80 & 0.66 & 0.79 & 4.39 & 0.65 & 1.61 \\
\hline 0.02 & 0.06 & 0.03 & 0.05 & 0.10 & 0.08 & 0.05 & 0.11 & 0.07 & 0.12 & 0.08 & 0.14 & 0.19 & 0.08 & 0.05 \\
\hline 0.15 & 0.59 & 0.38 & 0.47 & 0.34 & 0.46 & 0.12 & 0.15 & 0.54 & 0.56 & 0.07 & 0.17 & 1.85 & 0.04 & 0.22 \\
\hline 0.83 & 2.22 & 1.69 & 2.06 & 1.22 & 2.12 & 0.56 & 0.84 & 2.20 & 2.01 & 0.36 & 0.42 & 2.67 & 0.19 & 1.04 \\
\hline 2.84 & 3.99 & 3.65 & 3.82 & 3.86 & 4.03 & 3.68 & 3.67 & 3.80 & 3.84 & 4.22 & 3.97 & 4.35 & 2.99 & 3.70 \\
\hline 3.75 & 1.74 & 2.00 & 2.09 & 3.20 & 2.06 & 3.15 & 3.59 & 1.90 & 2.07 & 3.22 & 3.24 & 2.20 & 4.87 & 3.37 \\
\hline- & - & - & 0.03 & to & - & tr & - & 0.05 & - & 0.06 & - & - & 0.02 & 0.04 \\
\hline 0.01 & 0.01 & - & - & 0.01 & - & - & - & - & - & - & - & - & - & - \\
\hline 92.56 & 92.17 & 92.69 & 93.44 & 91.41 & 93.47 & 91.77 & 92.68 & 92.23 & 91.88 & 92.69 & 91.15 & 91.64 & 94.51 & 91.59 \\
\hline
\end{tabular}

clature of calc-alkaline lavas on $\mathrm{SiO}_{2} / \mathrm{K}_{2} \mathrm{O}$ diagrams (Fig. 6), we recorded 2 andesitic, 28 dacitic, 29 rhyodacitic, and 7 rhyolitic compositions.

As these data come from the same sampling and the same analysis series, their diversity reflects differences in volcanic source. Positive correlation of alkalis with $\mathrm{SiO}_{2}$ is generally linked to magmatic differentiation in calc-alkaline trends; the scatter perpendicular to this direction, following a negative correlation, is larger than the sampling variation (glass heterogeneity) and analytical drift. This spread shows the existence of several magmatic trends with different alkalinity, as in Legs 66 and 67 (Cadet et al., 1981 and 1982). Because potassium is classically the element used in the distinction of calc-alkaline lines, we separated the data into three groups$\mathrm{A}$, B, and $\mathrm{C}-$ on the $\mathrm{SiO}_{2} / \mathrm{K}_{2} \mathrm{O}$ diagram (Fig. 6), following limits parallel to differentation trends in order to detect a possibie evolution. To test this empiric subdivision, we performed a discriminant calculation-using MAHAL 3 (a computer program of Romeder, 1973), considering all the elements of the chemical analyses of the three groups; the calculation confirms the good sorting of over $80 \%$ of the samples in these groups. The first discriminant function includes as first significant variable $\mathrm{K}_{2} \mathrm{O}$, then $\mathrm{CaO}, \mathrm{Na}_{2} \mathrm{O}$, and $\mathrm{Al}_{2} \mathrm{O}_{3}$; the subdivision of groups is a distinction between calc-alkaline series. The first sorting using $\mathrm{K}_{2} \mathrm{O}$ and $\mathrm{SiO}_{2}$ in raw data (Fig. 6) can be considered satisfactory.

\section{Chronological Evolution}

The distinction of the products of more or less potassic lines or series eliminates the effect of differentiation and allows the chronological evolution of ash compositions to be plotted on a simple diagram: time $/ \mathrm{K}_{2} \mathrm{O}$ (Fig. 7). In this diagram, the $\mathrm{K}_{2} \mathrm{O}$ content is considered as a parameter including $\mathrm{SiO}_{2}$ (superposition of the groups).

In the Oligocene, dacites with a low potassic content appear. All three series appear in the lower Miocene as dacites and rhyodacites. They are found again in middle Miocene with highly potassic rhyolites. A single C-type, upper Miocene dacite sample has been analyzed. For the lower Pliocene, the sampling is limited to highly potassic andesites and dacites. The Pliocene-Pleistocene displays dacites, rhyodacites, and rhyolites from the three groups. Only low-potassic rhyodacites and rhyolites of group A have been analyzed for upper Pleistocene strata, but the other types do exist (cf., Leg 67, Cadet et al., 1982). Recent ash layers include moderately potassic an-

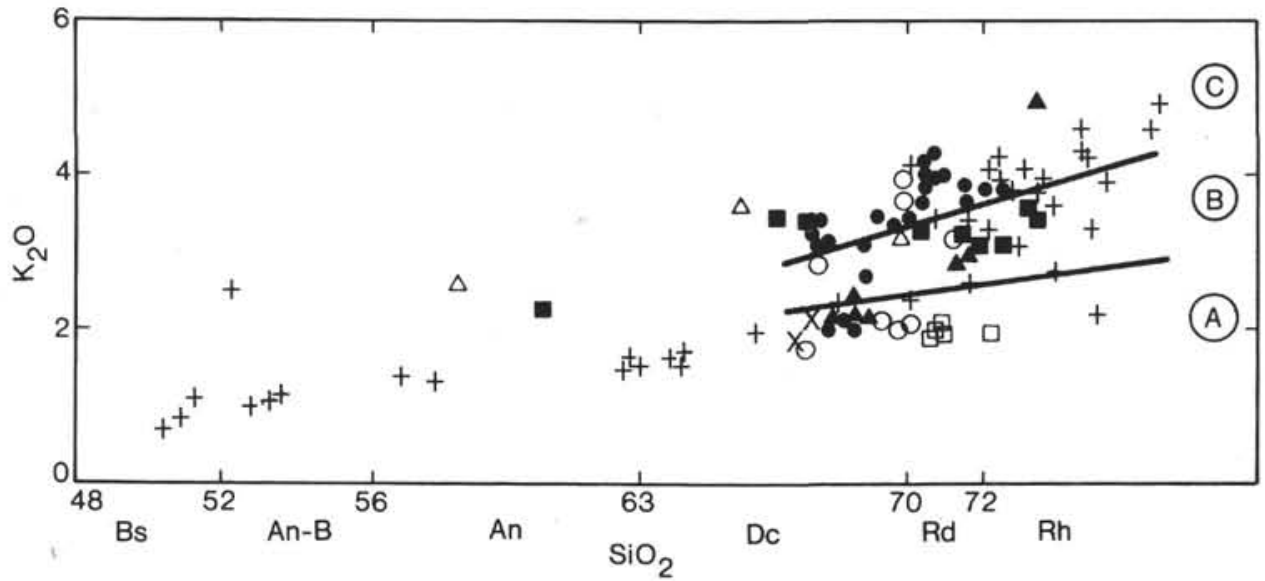

Figure 6. $\mathrm{K}_{2} \mathrm{O} / \mathrm{SiO}_{2}$ diagram (for an explanation of symbols denoting chronostratigraphic groups and petrographic identifications, see Fig. 5). Magmatic groups are $\mathrm{A}=$ low $\mathrm{K} ; \mathrm{B}=$ medium $\mathrm{K}$; and $\mathrm{C}=$ high $\mathrm{K}$. 


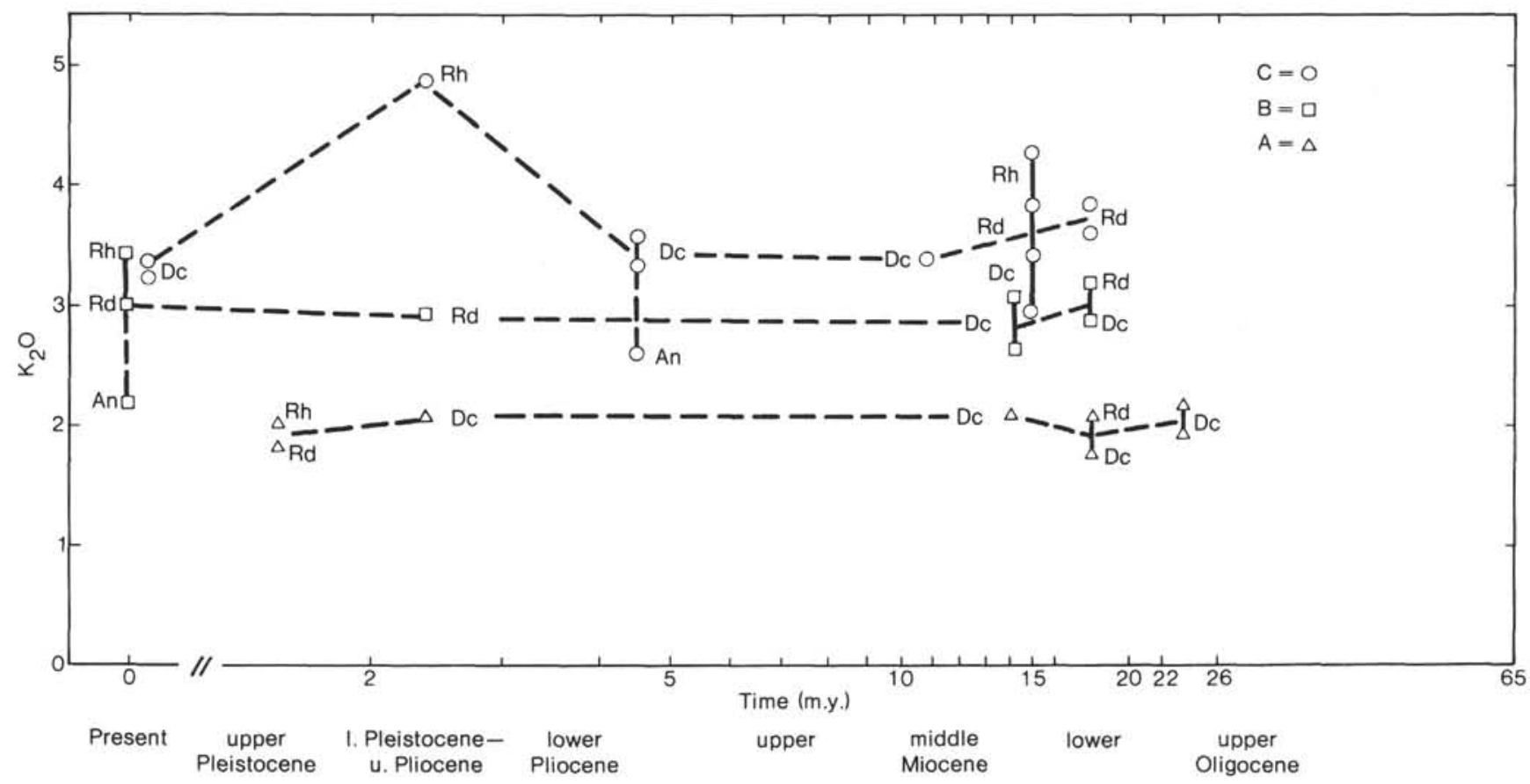

Figure 7. $\mathrm{K}_{2} \mathrm{O}$ /time diagram. Potassic groups: $\mathrm{A}=$ low $\mathrm{K} ; \mathrm{B}=$ medium $\mathrm{K}$; and $\mathrm{C}=$ high $\mathrm{K}$. For petrographic identifications (An, Dc, etc.) see Figure 5 .

desitic to rhyolitic glasses and a few highly potassic dacites.

A preliminary history of explosive volcanism of Central America since the Oligocene can be established in spite of insufficient sampling, taking into account the recording and the repartition of ash layers (i.e., loss of ash layers through alteration or erosional hiatuses). On the basis of two analyses, the first low potassic pulse appeared during the late Oligocene. A highly diversified magmatism developed during the early Miocene. This diversity remained in successive phases of activity: during the early Pliocene (preponderance of the highly potassic type), Pliocene-Pleistocene, and late Pleistocene. Only the moderate and high potassic series are represented in Recent sediments.

\section{Comparison with Leg 67}

Leg 67 includes 86 analyses of glasses sampled at four sites on the oceanic plates and the Trench lower slope (Cadet et al., 1982). The samples were analyzed using the BRGM-CNRS Camebax electron-probe microanalyzer in Orléans (France). Two sites, 496 and 497, were very close to Leg 84 at Sites 568 and 569; thus comparisons can be made on the same ash layers.

A shift in Leg 84 data, reflecting analytical conditions, was observed, with compositions systematically more alkaline and less siliceous (roughly $+0.5 \mathrm{~K}_{2} \mathrm{O}$ and $-2 \mathrm{SiO}_{2}$ ) than those obtained for Leg 67 materials. Consequently, there is a displacement of $\mathrm{AB}$ and $\mathrm{BC}$ limits on the $\mathrm{SiO}_{2} / \mathrm{K}_{2} \mathrm{O}$ diagram used in the Leg 67 chapter (Cadet et al., 1982). However, taking into account this analytical shift, data from the two legs can be combined.

Upper Oligocene strata was not reached in Leg 67. Lower Miocene A-group glasses (low potassium content) found at Site 496 have the same composition as those at Site 568 . B and C products are located at Site 569 but, as it seems, in a higher stratigraphic level of the lower Miocene. All compositions of the middle Miocene appear at the same Site 496. These data tend toward a diversification of lines from the beginning of the Miocene to the middle Miocene, a period of intense activity. Later, the existence of all these series in Leg 84 is supported by Leg 67 samples: line A at lower Pliocene at Site 497, line $C$ at the Pliocene-Pleistocene at the same site, line $\mathrm{C}$ equally (abundant) at upper Pleistocene at Site 496. Conversely, line A, limited to Pliocene-Pleistocene on Leg 67, reaches up to upper Pleistocene at Site 568.

\section{Comparison with On-Land Volcanism}

The deep-sea volcanic glasses studied here were originally explosive shards carried by winds from on-land volcanoes. In the area in question, the predominant winds are westerlies, as the El Chichon eruption clearly demonstrates (Robock and Matson, 1983). Thus in the north equatorial zone, the eastern Pacific mainly receives ashes from Guatemala, El Salvador, Costa Rica, and possibly southern Mexico. The eolian Central American origin of equatorial Pacific recent submarine ashes was geochemically verified by Boyles et al (1973). The silty size of shards and the presence of micropumice can correspond to eolian transportation exceeding distances of $100 \mathrm{~km}$ (Carey and Sigurdsson, 1980). There are no palagonitized glasses and no trace of submarine volcanism in the drilling area. Hot spots in the region are located farther southwest on Cocos Ridge (Lonsdale and Klitgord, 1978).

Comparison with on-land volcanism is limited by the scarcity of analyses of terrestrial glasses relative to analyses of lavas. Glassy materials are often, but not always, 
richer in alkalis than corresponding whole rocks. As a rule, rhyolitic glasses correspond to dacitic lavas, dacitic glasses to andesitic lavas, and so on.

On an AFM diagram (Fig. 8), glasses from Legs 67 and 84 are distributed in the "T sector" are of middle America Tertiary and Quaternary lavas of Woodruff et al. (1979). Intermediate to basic compositions are located in the FeO-rich part where analyses of on-land glasses and vitreous inclusions plot "G sector"; see Cadet et al., 1982).

$\mathrm{SiO}_{2} /\left(\mathrm{Na}_{2} \mathrm{O}+\mathrm{K}_{2} \mathrm{O}\right)$ and $\mathrm{SiO}_{2} / \mathrm{K}_{2} \mathrm{O}$ diagrams (Figs. 5 and 6 ) also show a selection of rhyolitic ash analyses from Guatemala and Columbia-Equador (Drexler et al., 1980) together with lava and glass compositions of Guatemala dacites and dacitic andesites (Rose, 1972a and b; Rose et al., 1978 and 1981; Bardintzeff et al., 1980). Acidic on-land samples are mainly located in moderately alkaline and potassic composition zones (groups B and C). Santiaguito dacitic glasses appear to have a low potassic content, but if statistical analyses takes into account all elements, these glasses are closer to the $\mathrm{C}$ group (Cadet et al., 1982). Basic lavas also have a low potassic content, but their glassy parts correspond to the $\mathrm{C}$ group.

In comparison, Columbia-Equador lavas have a higher potassic content than have Central America lavas, and so have South American volcanic materials, which clearly show a more calc-alkaline composition. However, some Columbia-Equador submarine glass samples of Leg 70, Galapagos (Schmincke, 1983), show a moderate alkalinity.

Tentative correlation of Recent deep-sea ash layers with Central American explosive deposits has been made using trace element data (INAA) on whole rock samples (Rose et al., 1982) or using principal component analysis with major elements composition (Cadet et al., 1982): Piños Altos and Los Chocoyos Quaternary tephra units of Guatemala correlate with Site 496 ash layers. Whole rock sample trace element correlation seems to be accurate. Major elements submarine glass chemistry may indicate an analytical analogy with on-land tephra, but the number of analyses is too low for a good statistical correlation.

\section{CONCLUSIONS}

1. Initiation of volcanism. The interbedding of ash layers in upper Oligocene mudstones recovered during Leg 84 allows the recording of a typical calc-alkaline volcanism of this age. This discovery may indicate that subduction had already begun in the Middle America Trench. There is evidence of an older volcanism during the late Eocene, offshore (Leg 84, Hole 569A) and onland through middle Eocene andesitic flows in Costa Ri-

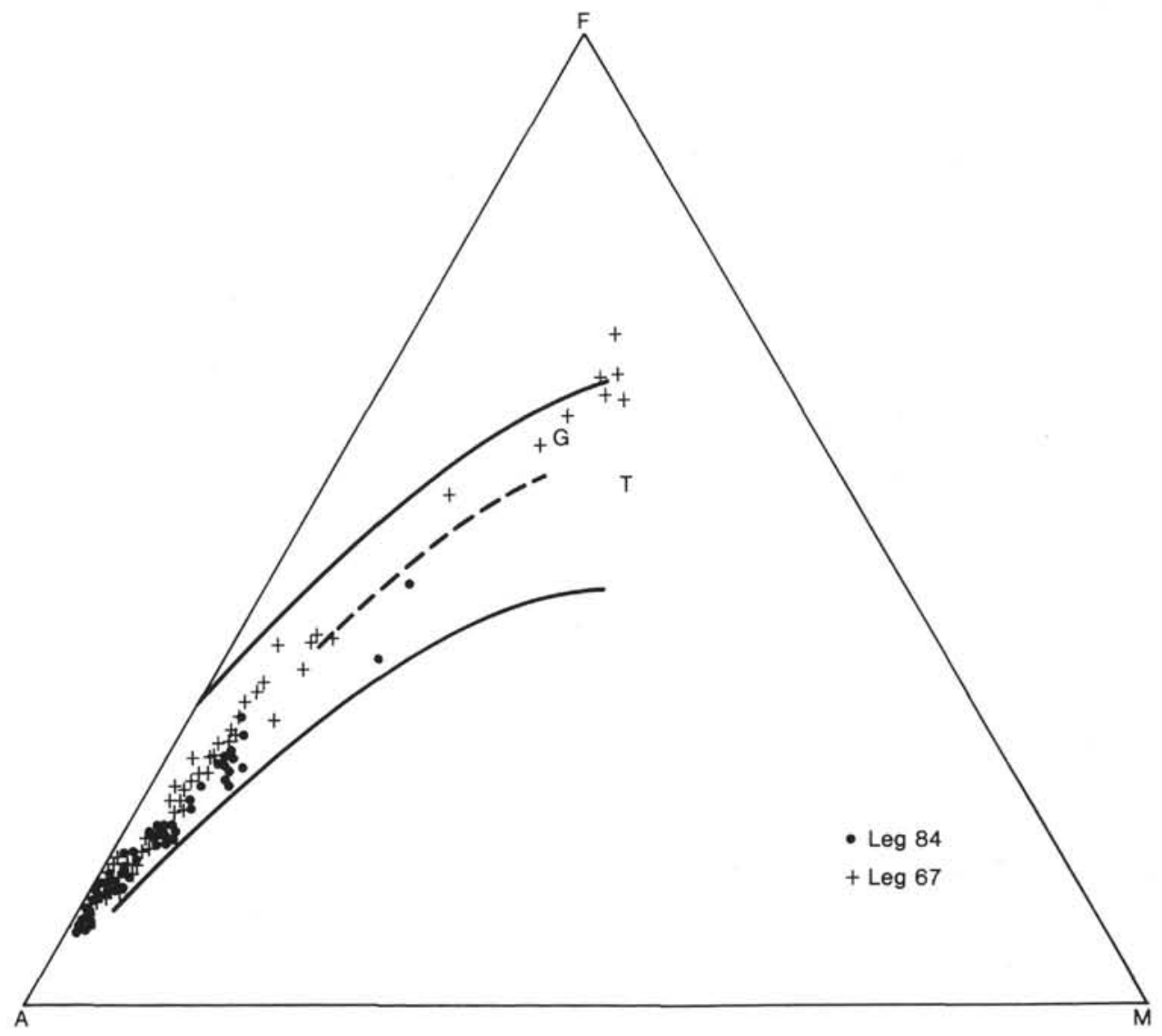

Figure 8. AFM diagram. Leg 67 (small crosses) and Leg 84 (black dots) glass analyses. $T=$ Central America volcanic rocks area; $\mathrm{G}=$ on-land tephras and glassy magmatic inclusions analysis sector. 
ca (Bellon and Tournon, 1978). Up to now this is the oldest known calc-alkaline volcanism in Central Ameri$\mathrm{ca}$, but its geodynamic meaning is not yet clear.

2. Magmatic evolution. At first, the magmatism seems to have a low- $\mathrm{K}_{2} \mathrm{O}$ character according to a few preliminary analyses; from the beginning of early Miocene, it diversifies into calc-alkaline potassic-differentiated lavas. If the hypothesis of a relationship between $\mathrm{K}_{2} \mathrm{O}$ content of primary magma and the dip of the Benioff zone (thus of depth of magma genesis) is followed (e.g., Keith, 1982), we can infer a correspondence of high subduction activity with the different periods of volcanism mainly during early-middle Miocene and late PliocenePleistocene. However, because the analyzed samples are acid glasses, it may be emphasized that the differentiated lavas maintained the more or less potassic character of their different lines following crystal fractionation conditions. At present, the volcanism has a medium to high potassic content. Indeed, the dip of the subduction plate (according to Molnar and Sykes, 1969) is steeper off Guatemala than it is to the northeast (South Mexico) and southeast (Panama). But the $\mathrm{K}_{2} \mathrm{O}$ content - Benioff dip relationship is still questioned; Carr et al. (1979) note that there is no correlation between $\mathrm{K}_{2} \mathrm{O}$ content and the depth of seismic focus in Central America. However, this observation only concerns recent lavas and does not take into account an evolution in time.

\section{ACKNOWLEDGMENTS}

We would like to acknowledge Dr. S. Bloomer, Dr. M. Baltuck, and an anonymous reviewer for their useful comments and their corrections of the manuscript, and P. Quienne and A. M. Dubois for their technical assistance.

\section{REFERENCES}

Aubouin, J., von Huene, R., Baltuck, M., Arnolt, R., Bourgois, J., Filewicz, M., Kvenvolden, K., Leinert, B., McDonald, T., McDougall, K., Ogawa, Y., Taylor, E., and Winsborough, B., 1982. Leg 84 of the Deep Sea Drilling Project; subduction without accretion: Middle America Trench off Guatemala. Nature, 297:458-460.

Aubouin, J., von Huene, R., et al., 1982. Init. Repts. DSDP, 67: Washington (U.S. Govt. Printing Office).

Bardintzeff, J. M., Brousse, R., Clochiatti, R., Weiss, J., 1980. Evolution des phénocristaux et de leurs inclusions magmatiques dans la "dacite" du dôme du Santiaguito (Guatemala). C.R Acad. Sci. Paris, 290(D): 743-746.

Bellon, H., and Tournon, J., 1978. Contribution de la géochronométrie K-Ar à l'étude du magmatisme de Costa Rica, Amérique Centrale. Bull. Soc. Geol. France, 7(XX No. 6):955-959.

Boyles, F. A., Jack, R. N., and Carmichael, I. S. E., 1973. Investigation of deep-sea volcanic ash layers from equatorial Pacific cores. Geol. Soc. Am. Bull., 84:2371-2388.

Cadet, J. P., Pouclet, A., Thisse, Y., Bardintzeff, J. M., and Azéma, J., 1982. Middle America Neogene explosive volcanism and ash layers: evidence from the Middle America Trench transect, In Aubouin, J., von Huene, R., et al., Init. Repts. DSDP, 67: Washington (U.S. Govt. Printing Office), 475-491.

Cadet, J. P., Thisse, Y., Pouclet, A., Bardintzeff, J. M., and Stephan, J. F., 1981. Tephra from Deep Sea Drilling Project Leg 66: Middle
America Trench transect (southern Mexico). In Watkins, J. S., Moore, J. C., et al., Init. Repts. DSDP, 66: Washington (U.S. Govt. Printing Office), 687-698.

Carey, S. N., and Sigurdsson, H., 1980. The Roseau ash: deep-sea tephra deposits from a major eruption on Dominica, Lesser Antilles Arc. J. Volcanol. Geotherm. Res., 7(1-2):67-86.

Carr, M. J., Rose, W. I., and Mayfield, D. G., 1979. Potassium content of lavas and depth of the seismic zone in Central America. $J$. Volcanol. Geotherm. Res., 5:387-401.

Drexler, J. W., Rose, W. I., Sparks, R. S. J., and Ledbetter, M. T., 1980. The Los Chocoyos ash, Guatemala: a major stratigraphic marker in Middle America and in three ocean basins. Quat. Res., $13: 327-345$.

Irvine, T. N., and Baragar, W. R. A., 1971. A guide to the chemical classification of the common volcanic rocks. Can. J. Earth Sci., 8: 523-548.

Keith, S. B., 1982. Paleoconvergence rates determined from $\mathrm{K}_{2} \mathrm{O}-\mathrm{SiO}_{2}$ ratio in magmatic rocks and their application to Cretaceous and Tertiary tectonic patterns in southwestern North America. Geol. Soc. Am. Bull., 93:524-532.

Kuno, H., 1968. Differentiation of basalt magmas. In Hess, H. H., and Poldervaart, A. (Eds.), Basalts (Vol. 2): New York (Interscience, Wiley), 623-688.

Lonsdale, P., and Klitgord, K. D., 1978. Structure and tectonic history of the Eastern Panama basin. Geol. Soc. Am. Bull., 89:981999.

Molnar, P., and Sykes, L. R., 1969. Tectonics of the Caribbean and Middle America regions from focal mechanisms and seismicity. Geol. Soc. Am. Bull., 80:1639-1684.

Pecerillo, A., and Taylor, S. R., 1976. Geochemistry of Eocene calcalkaline volcanic rocks from the Kastamonu area, Northern Turkey. Contrib. Mineral. Petrol., 58:63-81.

Robock, A., and Matson, M., 1983. Circum-global transport of the El Chichon volcanic dust cloud. Science, 221:195-197.

Romeder, J. M., 1973. Méthodes et Programmes d'Analyse Discriminante: Paris (Bordas Dunod Ed.).

Rose, W. I., 1972a. Santiaguito volcanic dome, Guatemala. Geol, Soc. Am. Bull., 83:1413-1434.

1972b. Notes on the 1902 eruption of Santa Maria volcano, Guatemala. Bull. Volcanol., 36:29-45.

Rose, W. I., Jr., Anderson, A. T., Woodruff, L. G., and Bonis, S. B., 1978. The October 1974 basaltic tephra from Fuego volcano; description and history of the magma body. J. Volcanol. Geotherm. Res., 4:3-53.

Rose, W. I., Jr., Bornhorst, T. J., and Drexler, J. W., 1982. Preliminary correlation of Quaternary volcanic ashes from the Middle America Trench off Guatemala, Deep Sea Drilling Project leg 67. In Aubouin, J., von Huene, R., et al., Init. Repts. DSDP, 67: Washington (U.S. Govt. Printing Office), 493-495.

Rose, W. I., Jr., Hahn, G. A., Drexler, J. W., Malinconico, M. L., Peterson, P. S., and Wunderman, R. L., 1981. Quaternary tephra of Northern Central America. In Self, S., and Sparks, R. S. J. (Eds.), Tephra Studies: Holland (D. Riedel Publ. Co.), pp. 193-211.

Schmincke, H. U., 1983. Rhyolitic and basaltic ashes from the Galapagos mounds area, Leg 70, Deep Sea Drilling Project. In Cann, J. R., Langseth, M. G., Honorez, J., Von Herzen, R. P., White, S. M., et al., Init. Repts. DSDP, 69: Washington (U.S. Govt. Printing Office), 451-457.

Woodruff, L. E., Rose, W. I., and Rigot, W., 1979. Contrasting fractionation patterns for sequential magmas from two calc-alkaline volcanoes in Central America. J. Volcanol. Geotherm. Res., 6: 217-240.

Date of Initial Receipt: 17 January 1984

Date of Acceptance: 21 April 1984 